\title{
The New World and the Old
}

\author{
By Nils Runeby
}

As long as the US has existed European interpreters have given their opinions about it. Critics and defenders have had their commitment in common. The confrontation between the constitutions of Europe and that of the US, and the social development of the two continents have been accompanied by violent ideological conflicus. The fact that the US has periodically exerted a strong artraction as a country of immigration has further contributed to the strengthening of the fronts. The interpretations have touched upon such essential themes that the scientific literature about them has assumed considcrable proportions in several countries.

That has not been the case in Sweden, and the existing literature is very limited. The only really comprehensive study which has been carricd out is Harald Elovson's deserving thesis "America in Swedish literature 1750-1820» and this appeared as early as 1930 . Besides this study there exists only a couple of short essays worth mentioning. Elovson wished to give an account of $» T$ the Liberal Image of America in Sweden" right o11 to our own days in a late study. (America and Scandinavia 1964), and Kjell Bondestad has given a survey of the change of the image of America during the decades before the Civil War in his study »The American Civil War and Swedish Public Opinion». In my own book $" T$ The New World and the Old. Image of America and Concept of Emigration in Sweden 1820-1860.»I have wished to draw attention to a research field which until now has been rather neglected.

Elovson and Rondestad have given certain general starting-points in the essays mentioned above. Elovson emphasizes the concept of America as a pattern, as $\gg$ the country of freedom, the country of the future, the model country» above all as related to constitutional law and social onder. In his thesis he summed up the American 
»civism»; he also emphasizes how the liberals depend on the Enlightenment in this respect, and he gives examples of several writers who represent this view of the US. However, Elovson does not go further than this general statement. Bondestad, too, emphasizes primarily the difference betwceu the liberal and the conservative views of America; those views developed into regular »myths». Both ways of vicwing arc said to have been modified in the middle of the 19th century, owing to increased knowledge about the US. Neither Elovson nor Bondestad has had reason to emphasize the dependency of the image of America on the domestic political development in the US, nor the changes of the political ways of thinking in Sweden during the period in question, nor the difficulties in attributing different elements of the image of Ainerica to the liberal or conservative bloc.

Several aspects can be derived from the literature of kindred subjects. In doing so one is stricken by the fact that the impulses from the US have often been judged in very favourable terms. This is true not least as regards studies of emigration. A parallell has often been made between opinions favouring America and liberalism, a striving for reforms, progress, and democracy.

A bricf exemplifying from Scandinavian researchers, or researchers who have touched upon Scandinavian conditions, can give an idea of the essence of the problem.

Halvdan Koht uses sweeping generalizations in his book $\gg$ The American Spirit in Europe» (1349). »The more the peoples of Europe began to shake the shackles laid upon them by their monarchical tyrants the more wistfully they looked upon the freedom prevailing across the ocean*. Koht called those who did not accept the US »antidemocrats» and $\gg$ the spokesmen of reaction». Books of travels about the US become san arsenal of weapons for the battle of ideologies which was taking place on the continent of Europe» for the two fighting phalanxes. America was and remained $\gg$ a source of inspiration for all democratic efforts in Europe,. 'In connection with the question of emigration Koht states his uniform opinions; »To the upper classes America appeared as a potential, in some respects already an actual, rival; to the lower class it was a promise and a hope».

Koht identifies without doubt an estimation of the US with ef- 
forts for democracy. Friends of America appear as progressive men in the fight against tyranny and oppression.

There is also a battle between the upper classes, which consider their hegemony threatened, and the lower classes which regard the US as a hope. Koht's opinions are not unique. »America came to symbolize the forces of change» Sigmund Skard writes in his book "The American Myth and the European Mindw (1961), »but these forces faced a solidly conservative and traditionalist Europe that came back in strenguh each time it was challenged».

Several emigration researchers have thought it necessary to try to establish a causal connection between emigration and creation of a favourable public opinion about the US. Therefore rhose researchers have often tried to estimate the influence of a special type of source material: the emigrant letters.

Even George Stephenson pointed out this causal connection in a wellknown essay, »When America Was the Land of Canaan». (Minnesota History 1929). He based his essay on Swedish material, mainly from the 1840's and 1850's. The emigrant who considered American equality, social mobility, religious liberty, and sobriety as opposed to conditions in Sweden, became an evangelist >,preaching the gospel of America to the heavy-laden. For him the year of jubilee had come». For Stephenson it was also a matter of unraveling psychological phenomena »for the theme of the historian of emigration is the human soul,,.

When Theodore Blegen published a volume of Norwegian emigrant letters in 1955, »Land of Their Choicew, he furnished it with an introduction where he pointed out that the emigrant letters also throw an interesting light on the debate about the merits of America in the native countries of the emigrants. The emigrants' image of the US is significant, Blegen says, not only as a testimony of what information was available to people in Europe in the middle of the 19 th century, but also as a propelling force in emigration itself». It became a dynamic factor $»$ bringing discontent to a focus and into action». Praise of the US »pointed to a contrast», and »turned discontent into resolution.»

Emigration and the image of America are coupled also by Ingrid Semmingsen; in an essay "Emigration and the Image of America in Europe» (Immigration and American History. Essays in honor of 
Theodore C. Blegen. 1961.) she investigates the image of the US, created by mass emigration in the classes from which this mass emigration came, and the impression exerted by this image on those who remained home. The emigrant letters talked about economic possibilities, cheap land, social equality, and local self government, and they became a stimulus to reforms. According to Semmingsen there was a connection between admiration of America and radicalism in Norwegian domestic policy. The influence of returners was also important. The contact with the US occasioned »the notion of change into the mind of the European peasant,,, and ideas about »social advancement, self improvement, and progress, all preconditions of political and social democracy» grew out of it. Whenever such movements arose in the native country of the emigrant it was influenced by emigration and contact with the US.

The backgnound of Swedish emigration has been described in similar categories. $O$. Fritiof Ander writes »America was virtually unknown in Sweden, before 1830. Discussions about the US were reserved for a small number of intellectuals. Another state of affairs arises with liberalism and reaction against the Metternich system. Europe is divided into two blocs: those who wanted to preserve the status quo and those who wanted to carry through reforms; America appeared an El Dorado to the reformers. The emignant letters exerted a profound influence. According to Ander it was above all the social liberty in the US that seemed attractive. (,Reflections on the Causes of Emigration from Sweden.,, Swedish Pioneer 1962.) Franklin D. Scott wished to point out humanitarian, religious, and democratic influences as the result of the American influence in Scandinavia. (»American Influences in Norway and Sweden., Journal of Modern History 1946). Scott points out in a study of the effects of emigration that the emigrant letters had exaggerated the benefits of the new country as well as the achievements of the writer himself. (Scandinavian Economic History Review 1960), but they created an image of a freer and better society, stimulated mass emigration and inspired reformers in the native countries of the emigrants. More generically »a stimulation of the mind, a widening of outlook, an inspiring sense of contact with a bigger world» were brought about. Such influences presumed, however, contacts with the emigrants, discontent with the native country, and susceptibility 
to new iinpressions, a consciously led opposition, and economic resources for reform activities.

At this point it may be necessary to state some critical distinctions. Merle Curti and Kendall Birr have discussed emigration and the image of America in Europe, 1860-1914. (Mississippi Valley Historical Review 1950). Also these authors emphasize the influence of the image of the US which where spread via emigrants' letters and returners, but they also have some distinct words to say about the propaganda organized by steamship lines, railway companies, and states in the US, as regards the forming of this iinage. »It offers» they say, »an excellent example of American intellectual imperialism.»

The authors also quote some theses about the reaction to emigration of »the favoured classes» in the native countries of the emigrants. They count upon two kinds of attitudes. According to the first one emigration should Ire favoured, because the domestic fights between »owners and workers» would be reduced through it. This searly nineteenth century Malthusian view of emigration as a necessary and desirable safety valve» gave way, however to another view, an opposition to emigration, influenced by mass emigration. This opposition was most apparent »among the state clergy, the official class, the great landowners, and the industrialists». The iinage of the US remained, according to the authors, at bottom rather stable, which can be explained by the fact that emigration had become commercialized and the image of America »a stereotype,,. When such a stereotyped image had been formed, it changed only very slowly. The US became in the eyes of the ruling classes, »a threat to the established institutions in Europe». The authority of the family, that of the state, and that of the church were threatened and above all »the prevailing class structure of society».

The idea of the European image of America during the 19th century which the authors mentioned above call forth, contains not only certain common characteristics but also seem to bear witness to a certain fundamental common attitude of the authors themselves: an appreciative estimation of the influences from the US and a favourable view of emigration and its effects. The emigrants were made to see an alternative to their own disatisfactory conditions and were encouraged to protest. The reformers whose efforts are 
now called liberal, now democratic, were inspired to act. A contrast between the »lower» classes and the »upper», the »established» ones which stand out as the advocates of the tradition-bound society were emphasized. Koht called them anti-democrats, Curti and Birr advocates of a prevailing class structure. The subjectively conjecturing elements of the stated analyses have to be emphasized.

\section{2.}

My study »The Neze World and the Old. Image of America and Concept of Emigration in Sweden 1820-1860» is intended to be an analysis of the image of America up to the time when this image has definitely been influenced by the debate about emigration. It is built up as an analysis of argument, and emigration is considered a domestic Swedish problem. My study begins where Elovson's dissertation stops. The time limit, 1820, was motivated by Elovson with the words »an important breach in the history of the general Swedish interest in America takes place around this year». This breach is caused by the Romanticism which occasions a »radical re-valuation of America» compared to the Enlightenment. The negative conception of the »tradition-less» US by the Romantics was in its turn attacked during the 1820's by »different representatives of the radical movements». » There is no equivalent to the discussion about the growing republic on the other side of the Atlantic which arose through this, during the period before 1820». European liberalism $»$ which in many respects is intimately dependent upon the Enlightenment,, takes over the favourable image of America of the Englightenment.

On the whole Elovson's limit can be accepted. However, one important argument can be added to the choice of the time around 1820 as a starting-point. Nowadays, in Swedish scientific literature, there exist such plain definitions of the ways of thinking politically in Sweden around 1820 that, as a consequence, useful classifications of the conservative as well as of the liberal way of thinking can be used. The existence of those ways of thinking can be established in the Swedish debate of that time. In this way the investigation can start from comparatively plain premises.

The final year, 1860, marks the American Civil War which forced the people of that time to reconsider their attitude towards the 
country. The war caused also a natural break of Swedish emigration. Furthermore 1860 means a change of the Swedish emigration legislation. Even the administrative conditions for emigration become different. Mass emigration from Sweden takes place also during the half century after the Civil War. The present study is accordingly chronologically entirely inside the scope of an early Swedish emigration, investigated only point by point. The year 1860 constitutes in this respect an inevitable dividing line.

Some further words about the aim of the investigation should be added. It must be emphasized that the material used is a relatively homogeneous one, so far as it is produced by a rather limited group of persons, journalists, officials, specialists, and professional writers, who have been able to give utterance to an opinion. Some of them can be followed during the whole of the epoch treated here. Matcrial has been taken outside this group only ori one or two occasions, above all material concerning parts of the religious emigration. It has also proved necessary to give isolated pieces of information about specific emigration undertakings, but this has only been done to identify the contributions and explain different points of view. I have, in this way, made an effort to produce a connected, mutually comparable material adapted to an analysis of arguments.

The material taken out of the press requires a special commentary. A difference with regard to the time before 1840 and after 1840 has been made in the material inventory. This is due to the state of affairs of emigration. Before 1840 emigration from Sweden was sporadic. Not until 1840 was a change of legislation carried out and this created possibilities of a more organized emigration. The 1840 's can be regarded as the first decade of mass emigration. The review of the press has been adopted with regard to these circumstances. The press material from before 1840 has been used point by point principally to illustrate private writers, essential to the debate about America. A complete excerpting has been carried out on twelve newspapers with long-standing publishing traditions after 1840. The provincial press has been chosen with regard to the emigration frequency of the provinces. The early emigration hit Sweden very unevenly, and the provincial newspapers chosen were published in districts which have been especially affected by emigration and where the existence of a detailed discussion of emigration 
questions has seemed probable. Certain trial investigations of the remaining provincial press have been undertaken, and those havc proved that material can be Found -- even if very divided -- but that it does not add any new characteristics to the established arguments. A number of papers of short duration has also been completely examined, while the remaining press has been used point by point. All through, the aim has been to establish the different kinds of argumentation, not to establish how many times they have been used.

The rest of the material - printed or unprinted - has consisted mainly of diplomats' reports, narratives of journeys, diaries, translated booklets and pamphlets, including emigrant guides, etc. I have also paid attention to official measures and parliamentary debate. Amplifications have been made with the aid of primate correspondence. The Swedish diplomatic reports from the US for the whole period havc been analysed. Narratives of travels, diaries etc., known to me havc been examined and considered to the extent that they have contained theorctic discussions important to the investigation. 01 coarse, it has not been a question of introducing a complete presentation but, on the other hand, my investigation claims to describe the existing arguments.

From what is said above it should be evident that for natural reasons the account of the period 1820-1840 will deal principally with the image of the US. The description of the following decades can be considered as applications and variations of the theme given in the first section, and as a confrontation between these and the conception of emigration. Emigration gave the US a nearness and a concretion that the country had not had earlier.

As to the represented kinds of arguments and the variations which can be established, the study has certain general results in common with i.e. René Rémond's voluminious and comprehensive thesis $\gg$ Les Etats Unis devant l'Opinion francaiseu (1962). Rémond treats the period from the Vienna congress to the establishment of the empire of Napoleon III, and registers very striking revulsions of the public feeling in connection with the July monarchy and the two French revolutions, as well as very evident changes of opinion in the political blocs. A couple of differences should be pointed out. In my description the emigration debate plays a prominent role. Rémond's 
aim is another. He claims to reflect the entire French opinion. $» C^{\prime}$ est l'opinion tout entière, qui nous intéresse» he emphasizes and he further points out $\gg I l$ s'agit d'un chapitre d'histoire de l'opinion et non d'histoire des idées politiques»... This aim oauses Rémond to come to far-reaching conclusions and to have rather ambitious discussions of a methodical kind; the validity of which may be questioned.

In my opinion this aim had made another method of procedure necessary.

\section{3.}

As far as opinions about the United States are concerned, it is not difficult to find instances of opposition between liberal and conservative writers from the early 1820 's. The liberals emphasize the representative constitution of the US, the absence of a guild system and inherited privileges. The conservatives, on the other hand, stress the empty and materialistic American commercial spirit, the absence of a historic individuality, and the lack of natural institutions formed by cultural and ethnic homogeneity. Of course it is necessary to point out these evident differences between a liberal and conservative American concept, but it is of equal importance to emphasize differences within the group of US admirers. One of the best known journalists of the 1820 's Johan Johansson, used the TJS as a pretext for defending the doctrine of division of power in which The Federalist was the American example. A. L. Klinckowström, a technical expert, who looked upon the US as a legal, humanistic and foremost technological leader, compared with Europe, was very sceptical about free trade and the limited scope of central authority. $\mathrm{He}$ emphasized the lower class tendency to abuse their freedom, and the recapability of European immigrants to sustain freedom in the US. In Sweden Klinckowström was supported by P. A. Wallmark, a journalist very much in favour with the King and also an active opponent to the conservative phalanx.

It is evident that admiration for the freedom, laws and humanism of the US must not necessarily be equated with liberalism; nor can it exclusively be connected with opposition to the King, the government or Swedish conditions in general. A widespread admira- 
tion for the US must not always mean that the same things were being admired by all people; and even less that one agreed to applications of the American experience.

One thing they had in common should, however, be emphasized. Lower class emancipation in the US caused obvious difficulties. In the translation of American literature there could be found traces of anxiety for the social equality in the US. Klinckowström and the conservative von Hartmansdorff both agreed on their unease with and dislike of social developments. The merchants Olof Wijk and C. D. Arfwedson diverged sharply in opinions about the US, but they both reacted very negatively to certain manifestations of American equalitarianism, and they both agreed completely on the existence of class differences in the US. Arfwedson expressed his dismay that the rich and literate classes could not restrain the lower classes.

In this context it is necessary to emphasize the changes in the US during the $1820^{\circ}$ s which caused changes in Swedish premises. The America which Klinokowström and Johan Johansson praised was not that of Jackson and Van Ruren. It was one thing to talk loftily about Washington's patrotism, quite another thing to acknowledge Jacksonian »democracy». Johansson praised the Federalists, Arfwedson praised Daniel Webster, and Wijk praised Henry Clay and the Whigs. These men spoke in friendly fashion about the enlightened minority in the US. At the end of the 1830's a conservative writer maintained chat the US had deserted the good heritage of Washington and the Federalists. There might be a strange community of interests between the friends and enemies of the US concerning a couple of essential points.

During the 1830's the situation in Sweden was not only influenced by Jacksonian democracy but also by events in Europe, above all by the French revolution of 1830 which created a more militant atmosphere. As far as Sweden is concerned attention must be paid to both the liberals around Lars Johan Hierta and Aftonbladet and those who praised the US because it was a republic, for at the end of the 1830's republican sentiments arose. Criticism against the US was pronounced by the conservatives and even also in the government organ Faderneslandet at the beginning of the 1830's. The debates show a tendency to become locked in argument. Tocqueville, 
in being translated into Swedish, was the victim of widely diverging conclusions.

The polemics of Aftonbladet show a couple of interesting complications when there is a need for defence in two directions. One must praise various forms of American liberty but, at the same time, must guarantee that there was no desire for a republic or a revolution, as was maintained by the opponents. Eventual lawlessness in the US was claimed to be due not to the system but to the roisterous immigrants. One way out of the dilemma of democracy, to evade the most threatening apprehensions for the fears of »mobocracy, was to emphasize the local self-government as the most positive aspect of the US. However, this latter could be appreciated for different reasons by ideological conservatives, as well as by a pleader for traditional aristocracy.

The difficulties which a republican US summoned up became obvious when voices were raised for a Swedish republic. But the US could also be criticized for not giving the promised equality, for after all there did exist class differences. In liberal ideology stress was put on the smiddle classes), at the expense of the hierarchy and institutions of the old society. Critics pointed out that the new society desired by the liberals gave much room for a new type of aristocracy, an aristocracy of money, and they emphasized its success in the US. In such a situation Aftonbladet could identify aristocracy with slaveholders or with opponents to Jackson. Aristocracy could then be condemned or defined in such a way as to remove any differences between aristocracy and the middle classes (the ruling of the best).

Because of their way of reasoning about the middle classes and financial aristocracy, liberals could be accused of a lack of interest in social reforms and concern for the lower classes. Discussions about Swedish pauperism were very common. With liberal arguments a writer of brochures could reject all thoughts about government intervention in the field of poor relief and also attack the existing poverty in Sweden. His solution was emigration. And in 1840 there was a loosening in the restrictive legislation on emigration, based on a bill introduced by Hierta.

Influences of developments in Europe and in the US can be noted also in the reports from Swedish diplomats in the United States 
during the forty-year-period investigated. Bernt Robert Stackelberg took openly the Whigs' part as to domestic questions. David Ankarloo talks disapprovingly of Jackson's flattery of the lower classes, and he deprecates the American party system, where the best (Whigs) are not capable of asserting themselves. Severin Lorich disapproves of the governmental banking policy, and he points out that enlightened and sensible people have another view of the matter and critizises the political system. Gustav af Nordin rejects the whole American system, the American and European republican passion and disapproves above all of the »ultra-democratic» party, and the unhappy influence of the masses on American politics. Adam Christian Lovenskiold declares that his natural attachment is with the US Whig-politicians who detest the revolution of the mob in Europe in 1848. Georg Sibern talks about the disastrous influence which is directed towards a violent and subverting democracy, brought into the US from Europe with bad radical elements among the immigrants. N.E.W. af Wetterstedt completely rejects the American party system, and is of the opinion that respectable Americans have nothing to do with politics, and that a "gang of cheats, thieves, and rascals), governs the country.

There is a quite definite, unmistakable trend in the conceptions of the United States of those seven Swedish diplomats. They experience the whole system as repulsive and they do not hesitate to take sides in domestic questions. The European influence which asserts itself is of a negative kind. For the diplomats the US served as place of banishment in their career. The stny in the US became an infliction of a penalty. Somewhat reluctantly they could allow that the US offered certain materialistic possibilities to poor immigrants, but the thought that the social and political structure of the country would give rise to advantages, as compared to the European monarchies was an impossibility.

\section{4.}

The double front of the liberals and the accusation partly of mobocracy and partly of plutocracy must be seen as one of the central themes in the US-debate, and it is not a matter of any great difficulties to follow the debate during the 1840's and the 1850's. In the shadow of the February revolution of 1848 Utopian social ideas 
spread in Sweden, with Proudhon as the leading spolresman. To these writers the US was an outstanding prototype, but an entirly different US than the country referred to by earlier writers. In this case the US was considered the country of social reforms, where attention was paid to workers' associations and great emphasis placed the combination of political liberty with achievement of economic equality. As a comparison one only needs to recollect the colonization attempts of Owen and the Icarian communitarians. On the other hand the struggle of liberalism is a fight for the bourgeoisie.

In consequence of the revolutions during the late 1840's and of the intensified discussion on communism, socialism, and organization of labour, it seemed necessary for a new generation of liberals to make clear distinctions between themselves and the Left. One could talk of the past generation as >>abstractiberals» emphasizing more interest in supporting ideas like nationalism and religion and less on French encyclopaedism. People of this new generation were, among others, those who bought I-Iierta's Aftonbladet and people like the American travcllcrs Siljeström and Frederika Bremer. Siljestrom's self-evident starting point is education, to which he gives an important moral significance. Knowledge implies honesty, religious feelings, loyalty and readiness to make sacrifices. All that he finds in the US. Sweden needed a renewed patriotism, a moral rearmament. Fredrika Bremer, influenced by Utopian ideas of associations, developed religious philanthropic visions. Liberty in combination with natural rights is not enough. To it must be added decency and morality in accordance with Christian traditions.

The debate about the religious liberty, one of the liberties noticed in the US is of interest in this context. The liberal fundamental principle is quite evident here, but the practical application could at times cause certain difficulties. In Sweden religious liberty and the prefigurativeness of the US were pointed out by sectarian movemenbs which the liberals could interpret as malignant manifestations of obscurantism and superstition. When Methodism appeared in Sweden its followers were accused also of political servility and lack of desire for social reforms; this accusation affected also the temperance movement which was often connected with church reform or sectarianism. A mutual misunderstanding, difficult to overcome, arose. 
The effects of religious liberty in the US were subjected to different interpretations, and at the beginning of the 50's its opposers were supported from an unexpected quarter. The Lutheran priest L. P. Esbjorn, who emigrated to the US in 1849, praising the religious conditions of the country, quickly revised his opinion once on the spot. Gustav Unonius, Esbjörn's antagonist during the 50's, who had emigrated at the beginning of the 40's and had stated his favourable impressions of the US in Aftonbladet, completely revised his opinion during the decade when he worked as an Anglican clergyman among Swedish emigrants. He now repudiated religious liberty as well as the US political system and urgently warned against emigration. At the end of the 50's when he wishes to return to Sweden, he says that he wants to contend for the State church and the Monarchy.

Discussions on religious liberty at the meeting of clergymen in Stockholm in 1853, where Unonius appeared, might illustrate the Swedish debate. The arguments against religious liberty included a fear of revolution, while religious liberty and emigration were elements tending to disturb social order. The adherents of religious liberty replied by giving a description of the US where religiosity played a most important role. Religious liberty neither disturbed civil order nor tended to moral decay. The US was a Christian country and it was conservative that is it watched over law and order. Subversive radicalism arrived with European immigrants, but was neutralized by the religious conciousness in the US (Siljeström). A remarkable fact in this special problem was that J. A. Hazelius, editor of the consevative Svenska Tidningen, was among those who defended the US.

The repudiation of emigration among different groups within the church is contrasted to opinions hound in separatist circles, for example the Norrland Hedbergians and the followers of the Baptist, Anders Wiberg. The situation in this connection is quite different. Wiberg clearly advocated propaganda for emigration with religious liberty as the main motive. And some of his friends tried to carry on a commercial emigrant business with ships which they purchased. To Wiberg the US and Sweden were one single working field where impulses came from the US and where it was impossible to have any profound doubts about the country and its institutions. But 
Wiberg rejected very firmly any sectarianism of a more political and revolutionary kind.

However, the opinions of Wiberg's followers were not homogeneous. In this context there could be doubts whether the emigration was consistent with the duties of a Christian. Wiberg's statements did not agree with those of his Icllow-believer, Gustav Palmqvist, whose negative experience of American religious life one would not want to spread in Sweden. On a more general appreciation of US liberties, they were on better terms and there is a striking contrast between these sectarians and Esbjörn and Unonius.

Swedish Lutheran clergymen in the US mere in a special situation. If Wiberg and his followers tried to Americanize Sweden, the Lutherans had to preserve Swedish culture in the US, save the immigrants from American influence, and describe the Lutheran church in the US as a branch of the Swedish church. Their communication with Sweden consisted of a continuous cry for help and support, accompanied by pessimistic reports on the general situation in the US. Papers with widely differing political views sympathized with them, for example Göteborgs Handels- och Sjöfartstidning, edited now by S. A. Hedlund, and the conservative Väktaren, while an adherent of religious liberty, H. B. Hammar, expressed his scepticism of their views. At the same time US Lutherans must defend the emigrants and guarantee that they would not be severed from their native country. The situation created a double view which disappeared only in judgment of the religious situation. The Lutheran church in Sweden and in the US fought the same battle against the tendency towards social and religious disorder.

5.

The obvious bond and the possible conflict between the image of America and emigration, pointed out in connection with the question of religious liberty and religious preservation in Sweden and in the US, can be illuminated from several angles and must be regarded as belonging to the most essential problems. Emigration should also be observed from some more general. angles. Schematically it may be possible to distinguish four different attitudes towards emigration during the period investigated. As the first def- 
intion I state the world-historic one: it was declared that migrations from the East to the West was something like a historic law, under which individuals and states had to submit. A variant, closely akin, was to refer to the conviction that the world government must have a deep meaning with all these migrations. The third variant used the quotation from the Bible about mankind spreading and filling the earth. Opinions of this kind have been pointed out in persons with very varied political domiciles. The even more general thought that emigration must have its way, that an intervention did not pay, presents a still more widespread support.

The second definition can be said to emerge from the thought of an existing or threatening over-population accompanied by pauperism where emigration offers a solution of the problem. This view is coloured by Malthusianism. It was this means that Petrus Laestadius pointed out in a booklet where he depicted Swedish poverty as flagrant and at the same time characterized relief measures of the central and local governments as impossible. It is also in this context that one must regard the efforts to establish Swedish colonies, emigration to which could be a patriotic act. The thought of colonization can primarily be traced from the beginning of the $40^{\circ} \mathrm{s}$, when C. F. Liljevalch, the wholesale dealer and shipowner, commanded a general attention to his activities. According to this opinion emigration should be regarded as a favourablc phenomenon which should be used in the national economy. The solution had international patterns.

The third possibility could come from about the same presumptions as the above, but emigration is then seen as a symptom which is ominous for Sweden. Measures are declared to be necessary for its removal. Here there are several definitions to note. The poverty and slavelike working conditions in Sweden were stressed almost like catch-words as an explanation to emigration. This explanation could be connected with the possibilities of acquiring land with the question of division of the free-hold farms. Here we find the principal liberal idea which defended the right of free division as a means of reducing emigration. Material could early be derived from the Norwegian debate. It can be established that the advantages of the right to free division of farms was questioned in the 40's also in the paper »Dagen», edited by the republicans. Again it is a ques- 
tion of the double front" of the liberals mentioned above. During a number of sessions of Swedish parliament the question reappeared, the number of parliamentary bills from the farmers' section of parliament was large and the opinions of the effects of the division and the interpretation of foreign experiences and its effect on emigration were diametrically opposed.

Further, if emigration is connected with the question of the labour migrations and the emigration of servants to Denmark and Norway the result is fruitful. Those who advocated a free labour market considered it a natural right of the individual to dispose of his labour freely. The price of labour was adjusted by the law of supply and demand. An exchange over the frontiers was in accordance with this view a quite natural effect of the system of free competition. As opposed to this opinion it was maintained that free emigration created a relationship between employer and employee, masters and servants, which imperiled public decency and endangered society. Furthermore it was said that the society's poor relief would be exposed to an overwhelming burden if impoverished emigrants returned home. Both views can be found in governors' reports, in the parliamentary debate, and in newspaper polemics. Persons who said that they advocated the right of free migration could feel some hesitation owing to those misgivings, and demands for more stringent regulations arose. Local attempts to bring pressure to bear and an animated local debate can be shown in the South and West of Sweden. In actual cases the adjustments between the different views could be rcasonably painful.

However, if emigration was considered an alarming symptom, more extensive explanations could also be recurred to. The reason was not only the need, the difficulty to acquire land, or low wages, it was the political and religious oppression, and among other things the lack of representation, which caused emigration. This view could, however, force one to emphasize that it was not overpopulation which threatened, not the poor, those in want of land etc. who emigrated, but relatively well-to-do citizens who had not the success and the political influence that they had a right to demand.

The fourth definition, finally, meant a denial of the existence of any real reasons for emigration. There were enough vacant jobs in Sweden, the supply of uncultivated land was good, no religious 
oppression existed; the US had no political advantages to offer compared to Sweden. Emigration was either due to partial newspaper propaganda, where the advantages of the US were praised without limits, or it had to be explained as a result of commercial recruitments or as a sign of the loosening tendencies of the time. In the most critical variant it could be said that those who emigrated were generally unreliable elements, whom Swedish society could well do without. However, emigration is primarily regarded here, as in the previous case, with regret.

To this can be added some further observations. Emigration actualized a number of apprehensions, repudiations, and demands. It must even be empliasized that there could arise conflicts also between the necessity to warn against emigration under the actual circumstances and a wish to maintain a favourable estimation of the US. This is evident both in the 1840's and 50's. It might result in an opposition between the view of the US as a theoretical phenomenon of political science and as an immigrant country.

Demands for state initiatives in the emigration question were taken up by different quarters. Those measures which were taken had a (tendency of reducing emigration but their scope was limited. The more stringent statements can be traced to local authorities. No rigorous regulations for the migrating labour were established, however, and in 1860 the system of compulsory passports was abolished. At the parliament of 1862-63 they discussed whether measures against emigration were to be taken and a publication by Unonius the contents of which would obstruct emigration was proposed. Unonius had before his departure from the US tried to carry out a questionnaire concerning, among other things, the wish to return to their native country among Swedish and Norwegian immigrants. The questionnaire gave, however, by all appearances no basis for measures. All propositions were also rejected by the parliament.

The exchange of arguments on the US and emigration during the period investigated is amazingly rich, even before the start of mass emigration from Sweden. A single division into conservatives and liberals does not always cover the interesting points in these arguments. It can also be shown quite clearly that as early as in the 1840 's one had to count with attempts to establish an organized 
emigrant traffic and evident economic interests behind the propaganda for emigration. Besides the simple fact that freedom is an ambiguous idea, the image of the land of freedom must already at that time be considered a commercialized slogan. By way of a guess discussions for the next fifty years might turn out to be variations of themes already known, at the same time as private initiative and the US of entrepreneurs became an ideal for the conservatives. 


\section{Nordic Emigration}

During the last years emigration research has developed rapidly in Scandinavia. In Finland and Sweden research groups are working on different problems concerning emigration from these countries to North America. In Norway and Denmark research in this field has been going on for a long time. Studies have also been initiated on the fascinating emigration from Iceland.

In September 1969 the first of a series of conferences on Nordic emigration was held in Uppsala, Sweden. Plans have now been worked out to start an Inter-Nordic research project on emigration. After the conference in Uppsala a report was published, containing the lectures held and summarizing the following discussions.

The program of the conference was:

1. Passenger Lists and Annual Parish Reports as Sources for the Study of Emigration from Sweden.

Introduction by Ingrid Eriksson

2. American and Nordic Source Material.

Introduction by Kristian Hvidt

3. General Theory and Models of Explanation.

Introduction by Sune Akerman

4. The Impact of Push and Pull.

Introduction by Charlotte Erickson and Fred Nilsson

5. Labour Migration - Migration - Emigration. Introduction by Göran Rosander

6. Selective Migration or Migratory Selectivity. Introduction by Sune $\AA$ kerman

7. The Distribution of Information and its Effects.

Introduction by Lars Ljungmark

The Information of the Emigrant Agencies.

Introduction by Berit Brattne

8. Re-immigration in its Connection with Emigration.

Introduction by Lars-Goran Tedebrand

Copies of the report can be ordered from Avdelningen för Amerikansk historia, S:t Larsgatan 2, S-752 20 Uppsala Sweden at a cost of $\$ 2$ (8 Swedish kronor). 